\title{
NITRATE IN COASTAL ANTARCTIC SHALLOW FIRN CORES: COMPARISON OF SEASONAL PATTERN AND OF TOTAL FLUX (Abstract)
}

by

\author{
K. Moser, D. Wagenbach and K.O. Münnich
}

(Institut für Umweltphysik, Universität Heidelberg, Im Neuenheimer Feld 366, 6900 Heidelberg, Federal Republic of Germany)

With the intention of contributing to a better understanding of snow depth profiles used in reconstructing the southern hemisphere nitrate background we have measured $\mathrm{Cl}^{-}, \mathrm{NO}_{3}^{-}$, and $\mathrm{SO}_{4}^{2-}$ in firn cores from two coastal Antarctic locations $\left(\mathrm{GvN}=\right.$ Ekströmisen $70^{\circ} \mathrm{S}, 8^{\circ} \mathrm{W}$, and Filchner $=$ Filchner-Ronne Ice Shelf $\left.79^{\circ} \mathrm{S}, 57^{\circ} \mathrm{W}\right)$. The depth resolution chosen is $2 \mathrm{~cm}$ per sample (i.e. 36 and 14 samples per year, respectively).

The isotopic composition of the firn cores was concurrently measured, with equally high resolution (deuterium and ${ }^{18} \mathrm{O}$ data, W. Graf, private communication). The GvN core yields an average accumulation rate of $35 \mathrm{~cm}$ $\mathrm{H}_{2} \mathrm{O}$ per year during the period 1979-86, while the Filchner core gives $14 \mathrm{~cm} \mathrm{H} \mathrm{H}_{2} \mathrm{O}$ per year during the period 1955-80. The net snow accumulation being relatively high allows precise determination of the year to year boundaries, as well as the relative contribution of individual seasons to the total net accumulation. This was achieved by combining the stable isotope data with the chemical tracers nss-sulfate (high concentration in summer) and sea salt (high $\mathrm{Cl}^{-}$in autumn and winter). For the two individual locations this procedure allowed assessment of the glacial nitrate concentration seasonality as well as comparing the yearly nitrate deposition.

The Filchner location shows a distinct seasonality with maximum concentrations in summer. For nearly half of the years covered we also find higher concentrations in winter. This higher nitrate in winter is always accompanied by high sea salt concentrations. We suggest therefore a mechanism making sea salt aerosol an additional deposition pathway for nitrate in winter. This means that we are not able to link the enhanced winter nitrate deposition to stratospheric denitrification directly. The $\mathrm{GvN}$ core does not show significant seasonality. This is presumably due to frequent snow drift events preventing signal conservation.

Although the individual accumulation rates differ by a factor of 2.5 the yearly nitrate deposition is in the same range $\left(4-11 \mathrm{~kg} \mathrm{NO}_{3}^{-}\left(\mathrm{km}^{-2} \mathrm{a}^{-1}\right)\right.$ at both sites. This is caused by the different seasonal modulation of the net snow accumulation. At GvN low nitrate autumn precipitation prevails and keeps the yearly nitrate level constantly low $(18-22 \mathrm{ppb})$. At Filchner, however, a high contribution of summer snow brings the yearly concentration average up to about $30-70 \mathrm{pbb}$.

\section{6-YEAR HIGH RESOLUTION PROFILE OF MAJOR ANIONS IN SNOW FROM COATS LAND, ANTARCTICA}

\author{
(Abstract) \\ by \\ R. Mulvaney, D.A. Peel, and A.P. Reid \\ (British Antarctic Survey, Natural Environment Research Council, High Cross, \\ Madingley Road, Cambridge CB3 OET, UK)
}

In January 1987, an $7.8 \mathrm{~m}$ core, with an age at the bottom of 26 years, was collected from a site approximately $150 \mathrm{~km}$ inland from Halley Station $\left(77^{\circ} 02.2^{\prime} \mathrm{S}, 22^{\circ} 32^{\prime} \mathrm{W}\right.$; altitude $1862 \mathrm{~m}$ a.s.1.); $10 \mathrm{~m}$ temperature $\approx-30^{\circ} \mathrm{C}$; accumulation rate $\approx 14 \mathrm{~g} \mathrm{~cm}^{-2} \mathrm{a}^{-1}$ ). The site lies some $140 \mathrm{~km}$ from the coast of the Weddell Sea and within the area bounded in winter by the polar vortex.

The core has been analysed at a frequency of $\approx 28$ samples per accumulation year for sulphate, nitrate and chloride, and has been dated stratigraphically from the clear seasonal cycles in non sea salt sulphate (Mulvaney and Peel, 1988). With this resolution it is possible to examine the seasonal pattern of deposition of chemical species and their phase relationships.

Of particular interest is the possibility that ice cores may preserve evidence for disturbances in tropospheric chemistry, associated with the recent spring-time depletion of stratospheric ozone. It has been proposed that this is accompanied by a denitrification of the stratosphere during the winter months, implying enhanced levels of $\mathrm{NO}_{\mathrm{x}}$ in the late winter/spring troposphere and in precipitation. Our data reveal a strong seasonal signal in nitrate deposition, apparently peaking in spring. Similar behaviour has been reported by Wagenbach and others (1988) for nitrate in the atmospheric aerosol, in a 3-year sequence (1983-86) from Georg von Neumayer Station $\left(70^{\circ} \mathrm{S}, 8^{\circ} \mathrm{W}\right)$. There does not appear to be any evidence in our data of an increase in spring-time nitrate deposition since the appearance of the Antarctic ozone hole in 1978.

\section{REFERENCES}

Mulvaney, R. and D.A. Peel. 1988. Anions and cations in ice cores from Dolleman Island and the Palmer Land plateau, Antarctic Peninsula. Ann. Glaciol., 10, 121-125.

Wagenbach, D., U. Gorlach, C. Moser, and K.D. Munnich. 1988. Coastal Antarctic aerosol: the seasonal pattern of its chemical composition and radionucleide content. Tellus, 40B, 426-436. 